\title{
Antimicrobial activity of microcapsules with aqueous extract of chambá (Justicia pectoralis Jacq) ${ }^{1}$
}

\author{
Atividade antimicrobiana de microcápsulas com extrato aquoso de chambá (Justicia \\ pectoralis Jacq)
}

\author{
Thays Lima Fama Guimarães ${ }^{2 *}$, Larissa Morais Ribeiro da Silva ${ }^{2}$, Carolline de Brito Lima ${ }^{2}$, Francisco Ernani \\ Alves Magalhães ${ }^{3}$ and Evânia altina Teixeira de Figueiredo ${ }^{2}$
}

\begin{abstract}
To ensure the antimicrobial activity of the aqueous extract of chambá, it is essential to protect its bioactive compounds. The objective was to preserve its characteristics, aiming to provide the food industry with a natural antimicrobial. Three microcapsule formulations made with maltodextrin and cyclodextrin were developed, both including the aqueous extract of chambá leaves dried through lyophilization. The aqueous extract was initially submitted to in vivo toxicity analysis using zebrafish and the microcapsules were characterized through studies of morphology, hygroscopicity, water solubility, particle size, zeta potential, color determination, microencapsulation efficiency and antimicrobial activity. The aqueous extract of chambá was not considered to be toxic. The microcapsules had irregular shapes, with sizes varying from 0.58 to 1.15 $\mu \mathrm{m}$. Solubility values ranged from 74.69 to $76.8 \%$ and hygroscopicity varied from 2.07 to $4.34 \%$. Additionally, it obtained efficient encapsulation of the phenolic compounds, showing antimicrobial activity against Staphylococcus aureus, Listeria monocytogenes, Salmonella Enteritidis and Escherichia coli, with its use being an alternative as a natural antimicrobial agent.
\end{abstract}

Key words: Aqueous extraction. Chambá leaves. Microencapsulation. Zebrafish. Microdilution.

RESUMO - Para assegurar a atividade antimicrobiana do extrato aquoso de chambá é essencial proteger seus compostos bioativos. Objetivou-se preservar as suas características, visando proporcionar a indústria de alimentos um antimicrobiano natural. Três formulações de microcápsulas foram elaboradas com maltodextrina e ciclodextrina, ambas juntamente com o extrato aquoso de folhas de chambá e secas por liofilização. O extrato aquoso foi inicialmente submetido à análise de toxicidade in vivo utilizando zebrafish e as microcápsulas foram caracterizadas por estudo da morfologia, higroscopicidade, solubilidade em água, tamanho de partículas, potencial zeta, determinação da cor, eficiência da microencapsulação e atividade antimicrobiana. O extrato aquoso de chambá não foi considerado tóxico. As microcápsulas apresentaram formas irregulares, tamanhos variando de 0,58 a 1,15 $\mu \mathrm{m}$. Valores de solubilidade de 74,69 a 76,8\%. A higrocospicidade variou de 2,07 a 4,34 \%. Além disso, obteve eficiente encapsulação dos compostos fenólicos, apresentando atividade antimicrobiana diante Staphylococcus aureus, Listeria monocytogenes, Salmonella Enteritidis e Escherichia coli, sendo uma alternativa sua utilização como antimicrobiano natural.

Palavras-chave: Extração aquosa. Folhas de chambá. Microencapsulação. Zebrafish. Microdiluição.

\footnotetext{
DOI: $10.5935 / 1806-6690.20200033$

*Author for correspondence

Received for publication on 08/10/2018; approved on 21/02/2020

${ }^{1}$ Trabalho extraído da Dissertação do primeiro autor apresentada ao Programa de Pós-Graduação em Ciência e Tecnologia de Alimentos, Universidade Federal do Ceará/UFC

${ }^{2}$ Programa de Pós-Graduação em Ciência e Tecnologia de Alimentos, Universidade Federal do Ceará/UFC, Fortaleza-CE, Brasil, thaysfama@ hotmail.com (ORCID ID 0000-0003-3644-8811), larissamrs @ yahoo.com.br (ORCID ID 0000-0001-7302-401X), carollineblima@ gmail.com (ORCID ID 0000-0003-4002-1845), evanialtina@gmail.com (ORCID ID 0000-0001-9209-0477)

${ }^{3}$ Laboratório de Bioprospecção de Produtos Naturais e Biotecnologia, Universidade Estadual do Ceará/UFC, Tauá-CE, Brasil, enrani.magalhaes@uece.br (ORCID ID 0000-0002-4924-2882)
} 


\section{INTRODUCTION}

The preservation of food products is a challenge for the food industry, considering that the use of synthetic preservatives can cause allergies and, in some cases, being considered carcinogenic. Thus, the demand for foods free of chemical preservatives has grown and there is an increase in the interest of industries for compounds of natural origin, due to their antimicrobial potential against pathogenic and deteriorating microorganisms (MARESCA et al., 2016).

The Brazilian biodiversity contains a variety of plants that have several biological properties. However, the constant use of specific parts of the plant can result in the extinction of the species. The use of leaves can be considered a good alternative for the preparation of extracts, as they are naturally renewable, which encourages scientific research in the area of bioactive and antimicrobial compounds (PINHO et al., 2011).

Chambá (Justicia pectoralis Jacq.), also called "fresh cut" in English, is a plant used by the population to treat respiratory diseases such as coughing, bronchitis and asthma. This domestic herb can be found in the countries of South, North or Central America, and is also used in Cuba, where it is called "tilo", in Jamaica "sana herida" and in Puerto Rico "san curia". In Brazil, in the North, Center-West and Northeast regions of Brazil, it is known as chambá, anador or trevo-cumaru (LEAL; SILVA; VIANA, 2017). Chambá shows antimicrobial activity against E. coli, E. faecalis, and Staphylococcus epidermidis (CORRÊA; ALCÂNTARA, 2012).

Chambá leaves can be an alternative raw material for the extraction of the natural antimicrobial compounds due to the active compounds present. Its main compound is coumarin (1,2 benzopyran) and umbelliferon, which have antimicrobial, anti-inflammatory, antioxidant and antiviral activity. Additionally, it also has flavonoids, saponins, tannins, lignin and 15 amino acids in its composition (CHANFRAU et al., 2013).

Encapsulation is a proposed alternative to protect bioactive compounds related to antimicrobial activity, being also related to the control of the encapsulated compounds release, masking the color, flavor and odor of the material, preventing heat degradation and oxidation when applied to foods (SHRESTHA; HO; BHANDARI, 2017).

Maltodextrin and cyclodextrin are considered the carbohydrates most often used as wall material for the encapsulation of bioactive compounds (REZENDE; NOGUEIRA; NARAIN, 2018). The development of microcapsules containing the aqueous extract of chambá aims to preserve its bioactive compounds and antimicrobial potential, aiming to provide the food industry with a natural antimicrobial with its preserved characteristics.

Therefore, the aim of the present study was to encapsulate the aqueous extract of chambá leaves to preserve its bioactive compounds, aiming to provide the food industry with a natural antimicrobial agent.

\section{MATERIAL AND METHODS}

The chambá leaves were obtained from the Medicinal Plants Nursery "Professor Francisco José de Abreu Mato" (Farmácia Viva), of the Federal University of Ceará(UFC), Fortaleza-Ceará. The Department of Biology confirmed the identity of the plant through the number of the desiccant, 60455, deposited at the Prisco Bezerra Herbarium of UFC. The strain of the sanitary (Escherichia coli ATCC 25922) and pathogenic indicator bacteria Salmonella Enteritidis (ATCC IAL 1132), Staphylococcus aureus (ATCC 27664) and Listeria monocytogenes (ATCC 19115) used in the study were obtained from the collection of bacteria of the Food Microbiology Laboratory - Food Department (DEAL), UFC.

\section{Preparation of the aqueous extract}

The aqueous extract was prepared by decoction, following the methodology of Bazylko et al. (2013), with adaptations. The dried and macerated chambá leaves were added to boiling water $\left(100{ }^{\circ} \mathrm{C}\right)$ for 5 minutes, at a proportion 1:40 m/v (dry leaves: water). The aqueous extract of chambá was placed in polyethylene containers, frozen and dehydrated through lyophilization (lyophilizer Model Beta 1-8 LD plus, CHRIST), compression of 0.025 mbar and temperature of $-40{ }^{\circ} \mathrm{C}$. Then, they were placed in opaque polyethylene containers and stored in a desiccator $\left(25^{\circ} \mathrm{C} \pm 1{ }^{\circ} \mathrm{C}\right)$, until the time of the analyses.

\section{In vivo toxicity using Zebrafish}

The aqueous extract was evaluated for in vivo toxicity using the zebrafish methodology proposed by Magalhães et al. (2017). The fish (Danio rerio) $(n=6 /$ group) were treated with aqueous extract of chambá at concentrations of $35 ; 70$ and $105 \mathrm{mg} / \mathrm{mL}$, representing the minimum bactericidal concentration found, double and triple that concentration, respectively or vehicle (sterile distilled water), with $20 \mu \mathrm{L}$ being administered orally. A group of animals without treatments was included (naive) for the open field test, to assess whether or not the animals motor coordination was altered, with the animals being added to glass Petri dishes $(10 \times 15 \mathrm{~cm})$, marked with four quadrants, analyzing locomotor activity by counting the number of crossed lines (CL). 
The CL value in the naive group was used as the baseline $(100 \%)$ and the percentages of locomotor activities (LA\%) were calculated individually for $0-5$ minutes. To assess acute toxicity, the animals were allowed to rest in order to analyze the mortality rate. After 96 hours of treatments, the number of dead fish in each group was recorded and the lethal concentration capable of killing $50 \%$ of the animals (LC50) was determined using the Trimmed Spearman-Karber mathematical method with a 95\% confidence interval (ARELLANO-AGUILAR et al., 2015).

\section{Preparation of microcapsules}

The microcapsules were obtained based on the adapted methodology of Silva et al. (2018). The aqueous extract of chambá leaves was used as the core and its mass was kept constant in the three prepared formulations, using $7.5 \%$ of extract and $30 \%$ of wall material in the solutions. The three formulations were made with maltodextrin (T1), cyclodextrin (T2) and a combination of maltodextrin and cyclodextrin 1:1 (T3). The wall materials were initially solubilized in water by stirring for 20 minutes in an ultrasonic bath (Model 03350C, Quimib).

The extract was added at a 1: $4 \mathrm{w} / \mathrm{w}$ ratio (extract: wall material) in each formulation and again taken to the ultrasonic bath for another 30 minutes. Subsequently, the dispersions were then homogenized using an Ultra-Turrax TE-102 homogenizer (Tecnal, Brazil) for 5 minutes at $14000 \mathrm{rpm}$. Then they were submitted to the freeze drying process (lyophilizer Model Beta 1-8 LD plus, CHRIST) with a pressure of 0.025 mbar and at a temperature of $-40{ }^{\circ} \mathrm{C}$.

\section{Morphology study}

The morphological study of the microcapsules was performed using the Inspect F50 scanning electron microscope. The samples were assembled with carbon steel tape ("stubs") and metallized with gold using the Quorum ${ }^{\circledR}$ Q150T ES system and inserted into the sample holder wells for reading, at magnifications of 112, 3500, 500 and 1000 times.

\section{Hygroscopicity}

The hygroscopicity analysis was determined as described by Goula and Adamopoulos (2008), where 1.0 $\mathrm{g}$ of each sample was weighed, in triplicate, on a Petri dish, spread evenly and submitted to the desiccator for 90 minutes, under a temperature of $24{ }^{\circ} \mathrm{C}$ and $75 \%$ relative humidity, using a saturated $\mathrm{NaCl}$ solution. The calculation was performed by the difference in mass and the results were expressed as a percentage of hygroscopicity.

\section{Solubility in water}

The solubility in water was assessed according to Yamashita et al. (2017), with adaptations. $0.25 \mathrm{~g}$ of the microcapsules were weighed in triplicate and $25 \mathrm{~mL}$ of distilled water were added. The solutions were then centrifuged at $3000 \mathrm{rpm}$ for 5 minutes and $20 \mathrm{~mL}$ of the supernatant was collected on Petri dishes, with weight being previously calculated. The plates were taken to the hot air oven at $105^{\circ} \mathrm{C}$ for 5 hours. Solubility was calculated by the difference in mass and the results were expressed as a percentage of solubility.

\section{Particle size and zeta potential}

The assessment of the mean particle diameter of the samples was performed using the Zeta Plus equipment (Brook Instruments Company, USA), by photon correlation spectroscopy (YAMASHITA et al., 2017). The zeta potential of the samples was measured using electrophoretic mobility measures at $25^{\circ} \mathrm{C}$.

\section{Color analysis}

The color analysis was determined using a Minolta colorimeter (model Choma-Meter CR410) and the coordinates were evaluated according to the CIELAB system $\left(\mathrm{L}, \mathrm{a}^{*}, \mathrm{~b}^{*}\right)$, Hue $\left(\mathrm{h}^{*}\right)$ and Chroma (c*) (ALVES; RESENDE; CRUVINEL, 2008).

\section{Microencapsulation efficiency}

To determine the encapsulation efficiency, the microcapsules $(1 \mathrm{mg} / \mathrm{mL})$ were homogenized and left to stand for 24 hours. After the time, the samples were filtered through UNIFIL paper filters. The encapsulation efficiency was calculated according to the following Equation 1 (GOMES; MOREIRA; CASTELL-PEREZ, 2011):

$$
\% E E=T P C-E P C / T P C \times 100
$$

Where: TPC represents total phenolic compounds and $E P C$, the concentration of encapsulated phenolic compounds.

\section{Antimicrobial activity of microcapsules}

The antimicrobial activity of the microcapsules was assessed using the microdilution method, according to the methodology described by Brandt et al. (2010), where the minimum inhibitory concentration (MIC) and the minimum bactericidal concentration (MBC) were determined. The tested concentrations of the microcapsules ranged from 5 to $200 \mathrm{mg} / \mathrm{mL}$ on the bacteria: E. coli, Listeria monocytogenes, Salmonella Enteritidis and Staphylococcus aureus. 


\section{Statistical Analysis}

The results were analyzed statistically by ANOVA and the levels of significance were determined by Tukey's Test at 5\% probability, using the statistical program Statistica 10.0. The data obtained in the analyses related to the antimicrobial effect of the chambá extracts were expressed through the minimum inhibitory and bactericidal concentrations.

\section{RESULTS AND DISCUSSION}

The aqueous extract of chambá did not have any sedative effect or caused locomotor impairment in the animals, considering that the animals showed significantly similar locomotor activity (LA) $(\mathrm{p}>0.05)$ between the sample groups, as well as in relation to the controls, naive $(\mathrm{LA}=100 \%)$ and vehicle $(\mathrm{LA}=92.9 \%)$ groups, as shown in Figure 1.

Figure 1 - Locomotor activity of adult zebrafish (Danio rerio) in the Open Field Test of aqueous extract of chambá leaves. Naive - untreated animals; p.o. - oral administration of the aqueous extract of the chambá (AECh); Vehicle - sterile distilled water (20 $\mu \mathrm{L}$; p.o.). The values represent the mean \pm standard error of the mean (S.E.M.) for 6 animals / group; ANOVA followed by Tukey's test. The numbers above each column indicate the percentage of locomotor activity (\% LA)

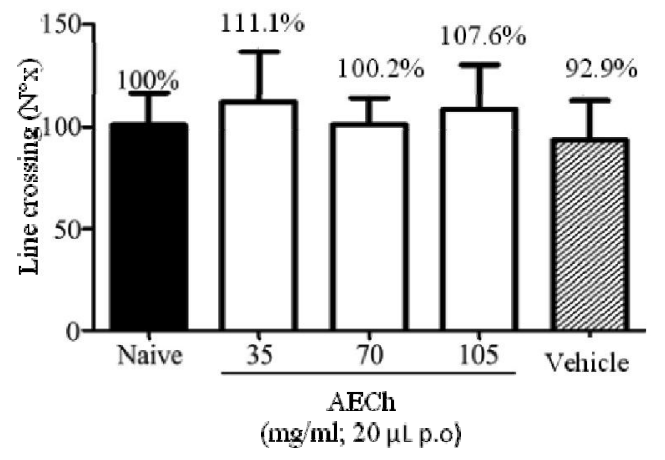

The locomotor activity is one of the behavioral analysis parameters that has been used to assess the action of drugs that can act upon the central nervous system of the adult zebrafish (Danio rerio) and cause locomotor impairment or not (TAYLOR et al., 2017). Nascimento et al. (2018), evaluating the behavioral effect of the flavonoid compound Kaempferol-3-O-rutinoside (KR), isolated from the Ouratea fieldingiana plant also on adult zebrafish, using as parameter the number of times the fish crossed the lines between the quadrants of a glass Petri dish during a specific time, determined that the KR did not alter the fish's locomotor system.

All tested concentrations (35, 75 and $105 \mathrm{mg} / \mathrm{mL})$ were shown to be safe, as they were not toxic within 96 hours of the analysis and did not cause the death of any fish.

The images of the microcapsules obtained by scanning electron microscopy are shown in Figure 2. Both treatments showed similar morphology, such as irregular shape, sharp particles and varied sizes. These characteristics are common in the encapsulants obtained by the freeze-drying technique (FRANCESCHINIS et al., 2014). For the non-encapsulated dry chambá extract (Figure 2A) larger particles were observed, but there was a reduction in size with the encapsulation. Ballesteros et al. (2017) using the lyophilization technique, maltodextrin and Arabic gum as wall material, observed morphologies that were similar to the ones obtained in this study.

Saikia, Mahnot and Mahanta (2015), when studying the microencapsulation of phenolic compounds from Averrhoa carambola bagasse by lyophilization also verified a reduction in the material particle size when encapsulating the matrix with maltodextrin, through lyophilization. Yamashita et al. (2017), in their study with microencapsulation of blackberry (Rubus spp.)

Figure 2 - Scanning electron microscopy images of the microcapsules. Dry aqueous extract of non-encapsulated chambá (A); Encapsulated with maltodextrin (B); Encapsulated with cyclodextrin (C); Encapsulated with maltodextrin and cyclodextrin (D)

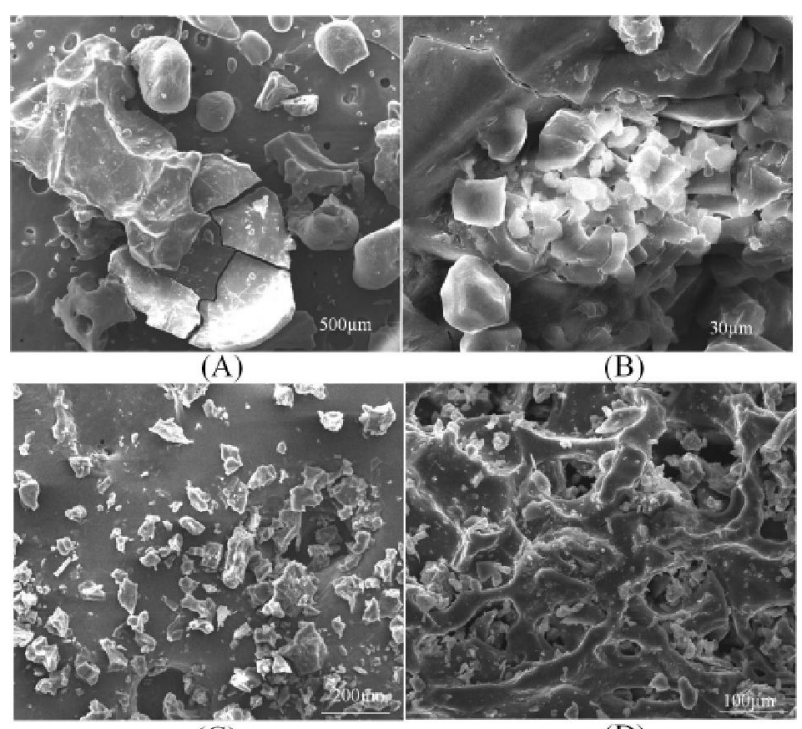

(C)

(D) 
by-product extract obtained by lyophilization, obtained micrographs of the microcapsules very similar to those obtained in this work.

The hygroscopicity values of the T1, T2 and T3 microcapsules were $2.07,4.34$ and $3.34 \%$, respectively, indicating that both the wall material and the dry aqueous extract of chambá are not hygroscopic, even when submitted to high relative humidity $(75 \%)$. This behavior is desirable to increase the product's shelf life and the preservation of bioactive compounds. Close values (2.37\%) were also reported by Toniazzo et al. (2017), when evaluating liposome-encapsulated quercetin by lyophilization.

Rezende, Nogueira and Narain (2018), studying the microencapsulation of bioactive compounds from extracts obtained from acerola (Malpighia emarginata D. C.) pulp and bagasse through atomization and lyophilization, found values within the range of $9.24 \%$ to $12.46 \%$, considering the low hygroscopicity of the powders, with the treatments being submitted to freeze drying showing the lowest values.

Considering that freeze drying was used in this study, and low hygroscopicity values were obtained, for this parameter it is suggested that the lyophilization technique is efficient to keep the product stable for a longer time.

Microcapsules made using only maltodextrin as a wall material showed less hygroscopicity than those made with cyclodextrin and the combination of the two wall materials, because maltodextrin is less hygroscopic (MOLLAN JUNIOR; ÇLELIK, 1996). Saikia, Mahnot and Mahanta (2015), microencapsulating phenolic compounds from Averrhoa carambola bagasse by lyophilization obtained less hygroscopicity with the increase of the maltodextrin content. The present study also observed that the treatment with a higher percentage of maltodextrin was less hygroscopic.

The solubility analysis showed no significant difference $(\mathrm{p}<0.05)$ between the evaluated microcapsule treatments. The T1, T2 and T3 treatments showed 75.8, 76.8 and $74.6 \%$ of solubility, respectively. Maltodextrin and cyclodextrin are soluble in water, but the lower values may be related to the possibility of the dry aqueous extract of chambá containing substances also with an apolar character. Silva et al. (2018), evaluating microcapsules of green tea dry extract extracted with a $75 \%$ ethanolic solution and encapsulated with a combination of maltodextrin and cashew gum, found similar values (63 to $72.66 \%$ ), also highlighting the hydrophobicity of the extract.

Saikia, Mahnot and Mahanta (2015), microencapsulating phenolic compounds of Averrhoa carambola bagasse by lyophilization and using maltodextrin as an encapsulant, found inferior results, ranging from 60.98 to $64.22 \%$. Calva-Estrada et al. (2018), encapsulating Vanilla planifolia Andrews with protein, obtained high solubility of the microcapsules (95.30\%), considering that the encapsulated material showed high solubility in water.

Solubility is related to the encapsulating agents used (maltodextrin and cyclodextrin). However, the lower solubility of the microcapsules may be related to the possibility of hydrophobicity of the dry extract of chambá leaves, preventing their total solubilization. In addition, considering the size of the particles and their agglomeration, the smaller the particles or the less agglomerated, the greater contact surface and better hydration (REZENDE; NOGUEIRA; NARAIN, 2018). The microcapsule with maltodextrin was larger $(1.15 \mu \mathrm{m})$, differing from the others $(\mathrm{p}<0.05)$. There was no difference when comparing the T2 and T3 microcapsules, with both showing $0.58 \mu \mathrm{m}$ in size. According to Azeredo (2005), the particle size can be classified as: macro $(>5000 \mu \mathrm{m})$, micro $(0.2-5000 \mu \mathrm{m})$ and nanocapsules $(<0.2 \mu \mathrm{m})$.

Microcapsules are more advantageous than nanocapsules, because the smaller the particle size, the greater the possibility of degradation, due to its greater surface/volume ratio (LABUSCHAGNE, 2018). The microcapsules did not show any significant differences regarding the zeta potential, at $5 \%$ of significance for the analysis of variance and by Tukey's test. In the present study, all particles showed a negative zeta potential of 14.97; -15.53; -16.17 mV for treatments T1, T2 and T3, respectively, indicating that the residual load of the chains present in the wall material is a negative one. The obtained values indicate instability, as according to Mishra et al. (2009), the zeta potential must be greater than $30 \mathrm{mV}$ (absolute value) to be stable.

The results of the color analysis are shown in Table 1. Regarding luminosity, a significant difference $(\mathrm{p}<0.05)$ was observed between the extracts, with the dry crude aqueous extract being darker than the microencapsulated ones, with low luminosity. Thus, it is emphasized that the wall material influenced the characteristics of the colors of the extracts, showing a statistical difference between the dry crude extract and the microcapsules, regarding all assessed variables. The microcapsule with cyclodextrin showed an L value closer to 100 (greater luminosity).

Parameters $a$ and $b$ showed positive values, indicating a trend towards the colors red and yellow, respectively. The chroma was higher for the microcapsules when compared to dry crude aqueous extract, indicating that these samples have better color purity, which is a desirable characteristic (REZENDE; NOGUEIRA; NARAIN, 2018). 
Table 1 - Values for the color parameters of the microcapsules and dry aqueous extract of chambá leaves. T1- aqueous extract with maltodextrin; T2- aqueous extract with cyclodextrin; T3- aqueous extract with maltodextrin and cyclodextrin. Means expressed as the same letters, in the same column, do not differ at the $5 \%$ level of significance with Tukey's test

\begin{tabular}{cccccc}
\hline Extracts & $\mathrm{L}$ & $\mathrm{A}$ & $\mathrm{b}$ & $\mathrm{c}$ & $\mathrm{h}$ \\
\hline $\mathrm{T} 1$ & $47.38 \mathrm{~b} \pm 4.83$ & $7.67 \mathrm{a} \pm 0.09$ & $29.54 \mathrm{a} \pm 0.03$ & $29.96 \mathrm{ab} \pm 0.78$ & $75.38 \mathrm{c} \pm 0.13$ \\
$\mathrm{~T} 2$ & $56.87 \mathrm{~d} \pm 0.15$ & $7.92 \mathrm{a} \pm 0.16$ & $29.69 \mathrm{a} \pm 0.25$ & $30.15 \mathrm{~b} \pm 0.28$ & $75.11 \mathrm{~b} \pm 0.13$ \\
$\mathrm{~T} 3$ & $53.5 \mathrm{c} \pm 0.12$ & $6.93 \mathrm{c} \pm 0.01$ & $27.81 \mathrm{c} \pm 0.09$ & $28.78 \mathrm{a} \pm 0.30$ & $75.92 \mathrm{~d} \pm 0.01$ \\
Aqueous & $25.14 \mathrm{a} \pm 0.21$ & $6.29 \mathrm{~b} \pm 0.05$ & $9.26 \mathrm{~b} \pm 0.14$ & $10.65 \mathrm{c} \pm 0.21$ & $55.75 \mathrm{a} \pm 0.03$ \\
\hline
\end{tabular}

The encapsulation efficiency results showed that the polysaccharides used for encapsulation had an important role in phenolic compound retention. Better encapsulation efficiency was found for the combination of maltodextrin and cyclodextrin, responsible for encapsulating $90 \%$ of the phenolic compounds present. However, for maltodextrin and cyclodextrin alone, the efficiency percentages were $80 \%$ and $78 \%$, respectively. This behavior can be explained by the fact that the encapsulation efficiency is highly dependent on the encapsulated compounds and the coating material used (ROSA et al., 2014).

Ballesteros et al. (2017) achieved lower encapsulation efficiency in their study with maltodextrin as a wall material, using the lyophilization technique. The authors encapsulated $63 \%$ of the phenolic compounds of coffee. Yamashita et al. (2017), in their study of anthocyanin microencapsulation with maltodextrin achieved a retention of up to $76 \%$, a lower value than that found in this study.

The lyophilization technique used for the microencapsulation of the aqueous extract of chambá was efficient to retain the bioactive compounds and, thus, preserve the extract antimicrobial effect on pathogenic bacteria.

Gram-positive bacteria showed greater sensitivity when compared to Gram-negative ones (Table 2). The microorganism that showed the lowest concentration need for inhibition and death was $S$. aureus for all tested extracts. Therefore, the microcapsules under study showed effective antibacterial action for this bacterium. The bacterium Salmonella Enteritidis showed higher MIC and $\mathrm{MBC}$, as it is more resistant. According to Nikaido (2003), because this bacterium is a Gram-negative microorganism and has an external membrane, it becomes less susceptible to the action of antibacterial substances. As for Listeria monocytogenes, even though it is a Gram-positive microorganism, it also required high concentrations; this may be related to the encapsulation efficiency, which was not $100 \%$ for microcapsules, and the fact that the present compounds were not sufficient to destroy its cell wall and inhibit its action.

The microcapsule made with maltodextrin was the only one that inhibited E. coli. According to Liu et al. (2017), as it is considered a resistant bacterium, this was the only microcapsule able to inhibit it.

Microcapsules are a good alternative for the food industry, as the color of the extract (Table 1) when encapsulated becomes less dark, thus probably not changing this attribute in foods. Moreover, encapsulation preserves the properties for longer periods, as it protects compounds from oxidation and other types of deterioration, increasing their stability and making their use as an additive more effective (BALLESTEROS et al., 2017).

Table 2 - Antimicrobial activity of microcapsules of the dry aqueous extract of chambá leaves. Minimum Inhibitory Concentration (MIC); Minimum Bactericidal Concentration (MBC); T1 - treatment with maltodextrin; T2 - treatment with cyclodextrin; T3 - treatment with maltodextrin and cyclodextrin

\begin{tabular}{ccccccccc}
\hline \multirow{2}{*}{ Extracts $(\mathrm{mg} / \mathrm{mL})$} & \multicolumn{2}{c}{ S. aureus } & \multicolumn{2}{c}{ L. monocytogenes } & \multicolumn{2}{c}{ S. Enteritidis } & \multicolumn{2}{c}{ E. coli } \\
\cline { 2 - 8 } & MIC & MBC & MIC & MBC & MIC & MBC & MIC & MBC \\
\hline T1 & 5 & 5 & 100 & 150 & 200 & 200 & 200 & - \\
T2 & 5 & 5 & 90 & 90 & 140 & 140 & - & - \\
T3 & 5 & 5 & 90 & 90 & 150 & 180 & - & - \\
\hline
\end{tabular}




\section{CONCLUSION}

The microcapsules showed efficient encapsulation of the phenolic compounds and antimicrobial activity. The microcapsule made with maltodextrin (T1) was the only one that attained MIC for all bacteria. The encapsulation of the aqueous extract is an alternative for the preservation of its constituents and properties, as an antimicrobial potential for application in the food industry as a natural antimicrobial agent.

\section{ACKNOWLEDGEMENTS}

The authors would like to thank the Cearense Foundation for Supporting Scientific and Technological Development (FUNCAP), the National Council for Scientific and Technological Development (CNPq), the Food Microbiology Laboratory (UFC), Technological Development Park (PADETEC), Brazilian Agricultural Research Corporation (Embrapa), Laboratory of Bioprospecting of Natural Products and Biotechnology (LBPNB), Laboratory of Polymers and Material Innovations (UFC) and Analytical Center UFC/CTINFRA/MCTI-SISNANO/ Pro-Equipment.

\section{REFERENCES}

ALVES, C. C. O.; RESENDE, J. V.; CRUVINEL, R. S. R. et al. Estabilidade da microestrutura e do teor de carotenóides de pós obtidos da polpa de pequi (Caryocar brasiliense Camb.) lioflizada. Ciência e Tecnologia de Alimentos, v. 28, n. 4, p. 830-839, 2008.

ARELLANO-AGUIAR, O. et al. Use of the zebrafish embryo toxicity test for risk assessment purpose: case study. Journal of Fisheriessciences, v. 9, n. 4, p. 52-62, 2015.

AZEREDO, H. M. C. Encapsulação: aplicação à tecnologia de alimentos. Alimentos Nutricionais, v. 16, n. 1, p. 89-97, 2005.

BALLESTEROS, L. F. et al. Encapsulation of antioxidant phenolic compounds extracted from spent coffee grounds by freeze-drying and spray-drying using different coating materials. Food Chemistry, v. 237, p. 623-631, 2017.

BAZYLKO, A. et al. Comparison of antioxidant, antiinflammatory, antimicrobial activity and chemical composition of aqueous and hydroethanolic extracts of the herb of Tropaeolum majus L. Industrial Crops And Products, v. 50, p. 88-94, 2013.

BRANDT, A. L. et al. Inhibition of Listeria monocytogenes by food antimicrobials applied singly and in combination. Journal of Food Science, v. 75, n. 9, p. 557-563, 2010.

CALVA-ESTRADA, S. J. et al. Microencapsulation of vanilla (Vanilla planifolia Andrews) and powder characterization. Powder Technology, v. 323, p. 416-423, 2018.
CHANFRAU, J. E. R. et al. Obtention of dry extract from aqueous extracts of Justicia pectoralis Jacq. (tilo). Revista Cubana de Plantas Medicinales, v. 18, n. 4, p. 543-554, 2013.

CORRÊA, G. M.; ALCÂNTARA, A. F. C. Chemical constituents and biological activities of species of Justicia: a review. Brazilian Journal of Pharmacognosy, v. 22, n. 1, p. 220-238, 2012.

FRANCESCHINIS, L. et al. Physical and functional properties of blackberry freeze- and spray-dried powders. Drying Technology, v. 32, p. 197-207, 2014.

GOMES, C.; MOREIRA, R. G.; CASTELL-PEREZ, E. Poly (DL-lactide-co-glycolide) (PLGA) Nanoparticles with entrapped trans-cinnamaldehyde and eugenol for antimicrobial delivery applications. Journal of Food Science, v. 76, n. 2, p. 16-24, 2011.

GOUlA, A. M.; ADAMOPOUlOS, K. G. Effect of maltodextrin addition during spray drying of tomato pulp in dehumidified air: II. powder properties. Drying Technology, v. 26, p. $726-737,2008$.

LABUSCHAGNE, P. Impact of wall material physicochemical characteristics on the stability of encapsulated phytochemicals: a review. Food Research International, v. 107, p. 227-247, 2018.

LEAL, L. K. A. M.; SILVA, A. H.; VIANA, G. S. B. Justicia pectoralis, a coumarin medicinal plant have potential for the development of antiasthmatic drugs? Revista Brasileira de Farmacognosia, v. 27, p. 794-802, 2017.

LIU, Gu. et al. Antibacterial activity and mechanism of bifidocin A against Listeria monocytogenes. Food Control, v. 73, p. 854-861, 2017.

MAGALHÃES, F. E. A. et al. Adult zebrafish (Danio rerio): an alternative behaviora model of formalin-induced nociception. Zebrafish, v. 14, n. 5, p. 422-429, 2017.

MARESCA, D. et al. Microencapsulation of nisin in alginate beads by vibrating technology: preliminary investigation. Lwt - Food Science And Technology, v. 66, p. 436-443, 2016.

MISHRA, P. R. et al. Production and characterization of Hesperetin nano suspensions for dermal delivery. International Journal of Pharmaceutics, v. 371, p. 182-189, 2009.

MOLLAN JUNIOR, M. J.; ÇLELIK, M. Maltodextrin. Analytical Profiles Of Drug Substances And Excipients, v. 24, p. 307-349, 1996.

NASCIMENTO, J. E. T. et al. The orafacial antinociceptive effect of Kaempferol-3-O -rutinoside, isolated from the plant Ouratea fieldingiana, on adult zebrafish (Danio rerio). Biomedicine \& Pharmacotherapy, v. 107, n. 1, p. 1030-1036, 2018.

NIKAIDO, H. Molecular basis of bacterial outer membrane permeability evisited. Microbiology and Molecular Biology Reviews, v. 67, n. 4, p. 593-656, 2003.

PINHO, L. et al. Atividade antimicrobiana de extratos hidroalcóolicos das folhas de alecrim- pimenta, aroeira, barbatimão, erva baleeira e do farelo da casca de pequi. Ciência Rural, v. 42, n. 2, p. 1-6, 2011. 
REZENDE, Y. R. R. S.; NOGUEIRA, J. P.; NARAIN, N. Microencapsulation of extracts of bioactive compounds obtained from acerola (Malpighia emarginata DC) pulp and residue by spray and freeze drying: chemical, morphological and chemometric characterization. Food Chemistry, v. 254, p. 281-291, 2018.

ROSA, C. G. et al. Encapsulation of the phenolic compounds of the blackberry (Rubus fruticosus). LWT- Food Science and Technology, v. 58, n. 2, p. 527-533, 2014.

SAIKIA, S.; MAHNOT, N. K.; MAHANTA, C. L. Optimisation of phenolic extraction from Averrhoa carambola pomace by response surface methodology and its microencapsulation by spray and freeze drying. Food Chemistry, v. 71, p. 144-152, 2015.

SHRESTHA, M.; HO, T. M.; BHANDARI, B. R. Encapsulation of tea tree oil by amorphous beta-cyclodextrin powder. Food Chemistry, v. 221, p. 1474-1483, 2017.
SILVA, F. et al. Cashew gum and maltrodextrin particles for green tea (Camellia sinensis var Assamica) extract encapsulation. Food Chemistry, v. 261, p.169-175, 2018.

TAYLOR, J. C. et al. A novel zebrafish-based model of nociception. Physiology \& Behavior, v. 174, p. 83-88, 2017.

TONIAZZO, T. et al. Encapsulation of quercetin in liposomes by ethanol injection and physicochemical characterization of dispersions and lyophilized vesicles. Food Bioscience, v. 19, p. 17-25, 2017.

YAMASHITA, C. et al. Microencapsulation of an anthocyaninrich blackberry (Rubus spp.) by-product extract by freezedrying. LWT - Food Science And Technology, v. 84, p. 256$262,2017$. 